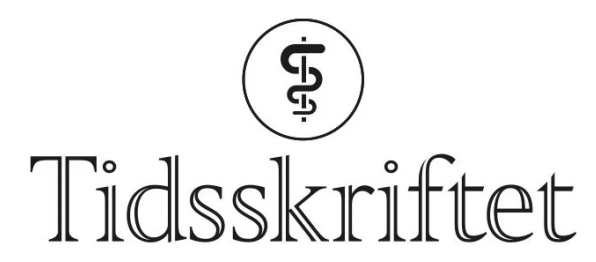

DEN NORSKE LEGEFORENING

\title{
Forsinket pleuraeffusjon etter thoraxtraume
}

KORT KASUISTIKK

IDAR JOHAN BREKKE

idar.j.brekke@gmail.com

Hjerte-lungekirurgisk afdeling

Aalborg universitetshospital

Idar Johan Brekke er lege.

Forfatteren har fylt ut ICMJE-skjemaet og oppgir ingen interessekonflikter.

\section{PANAGIOTIS MAIDAS}

Radiologisk afdeling

Aalborg universitetshospital

Panagiotis Maidas er spesialist og overlege.

Forfatteren har fylt ut ICMJE-skjemaet og oppgir ingen interessekonflikter.

\section{LARS MøLLER}

Hjerte-lungekirurgisk afdeling

Aalborg universitetshospital

Lars Møller er spesialist og overlege. Han er formann for Dansk thoraxkirurgisk selskab.

Forfatteren har fylt ut ICMJE-skjemaet og oppgir ingen interessekonflikter.

De fleste thoraxtraumer er ikke innleggelseskrevende, men komplikasjonene kan være mange. Pleuraeffusjon er blant de vanligste som krever behandling. Denne kasuistikken beskriver et atypisk forløp hos en pasient med forsinket pleuraeffusjon etter ribbeinsbrudd.

En mann i 6o-årene ble mottatt som traumepasient etter å ha vært forsetepassasjer i en kollisjon mellom to personbiler. Ved ankomst var han stabil, og den kliniske undersøkelsen avdekket kun palpasjonsømhet over venstre hemithorax. CT-undersøkelse fra hodet til bekkenet ble foretatt i traumeprotokoll og viste brudd på 2.-9. ribbein på venstre side, med dobbeltbrudd på flere ribbein, samt et omkringliggende, mindre hematom. Det var ikke tegn til intratorakale eller intraabdominale skader. De første dagene etter innleggelsen var pasienten en del plaget av smerter. Han hadde god effekt av peroral smertebehandling, og det var ikke tegn til respirasjonsinsuffisiens. Etter fem dagers innleggelse var han i god bedring og ble utskrevet. 
Ved poliklinisk kontroll to uker senere hadde pasienten kun lette smerter, men røntgen thorax viste en betydelig mengde pleuraeffusjon på venstre side, og han ble innlagt til pleurapunksjon. Ved klinisk undersøkelse var det dempning over venstre lungeflate, perifer oksygenmetning på $97 \%$, blodtrykk på $138 / 84 \mathrm{~mm} \mathrm{Hg}$, puls på $84 \mathrm{slag} / \mathrm{min}$ og hemoglobinkonsentrasjon på 10,5 g/dL (referanseområde 13,4-17,0). Et 6 frenchgrisehalekateter ble anlagt ultralydveiledet, og det ble umiddelbart drenert omkring én liter serøs-blodig væske. I de påfølgende døgnene var det sparsom produksjon på drenet til tross for skylling med $100 \mathrm{~mL}$ saltvann tre ganger daglig. På tredje dag etter innleggelsen viste røntgen thorax fortsatt en stor, udrenert væskeansamling. Det ble igangsatt behandling med intrapleural fibrinolyse i form av $10 \mathrm{mg}$ alteplase daglig i tre dager.

Etter to dagers behandling med alteplase ble pasienten utilpass med smerter i venstre hemithorax. Symptomene lettet da han la seg i sengen. Det ble like etterpå målt blodtrykk på 130/8o mm Hg, puls på $70 \mathrm{slag} / \mathrm{min}$, perifer oksygenmetning på $97 \%$ og registrert $400 \mathrm{~mL}$ blodig væske i drenposen. Noen timer senere ble pasienten igjen utilpass, og det ble målt blodtrykksfall til 55/30 mm Hg. Kontroll av hemoglobin viste et fall fra 9,4 til 8,2 g/dL i løpet av dagen. Tilstanden stabiliserte seg med intravenøs væskebehandling og en enhet erytrocytter. Pasienten var våken og blek, og blodtrykket var 10o/6o mm Hg. Røntgen thorax viste tiltagende pleuraeffusjon (figur 1), og påfølgende CT thorax konstaterte massiv hemothorax med forskyvning av mediastinum samt en blødningssuspekt lesjon i relasjon til diafragma (figur 2). Tilbake på avdelingen hadde pasienten tiltagende takykardi med puls på $118 \mathrm{slag} / \mathrm{min}$. Blodtrykket var 110/72 $\mathrm{mm} \mathrm{Hg}$. Det ble lagt et 28 french-pleuradren akutt og tappet én liter blod.

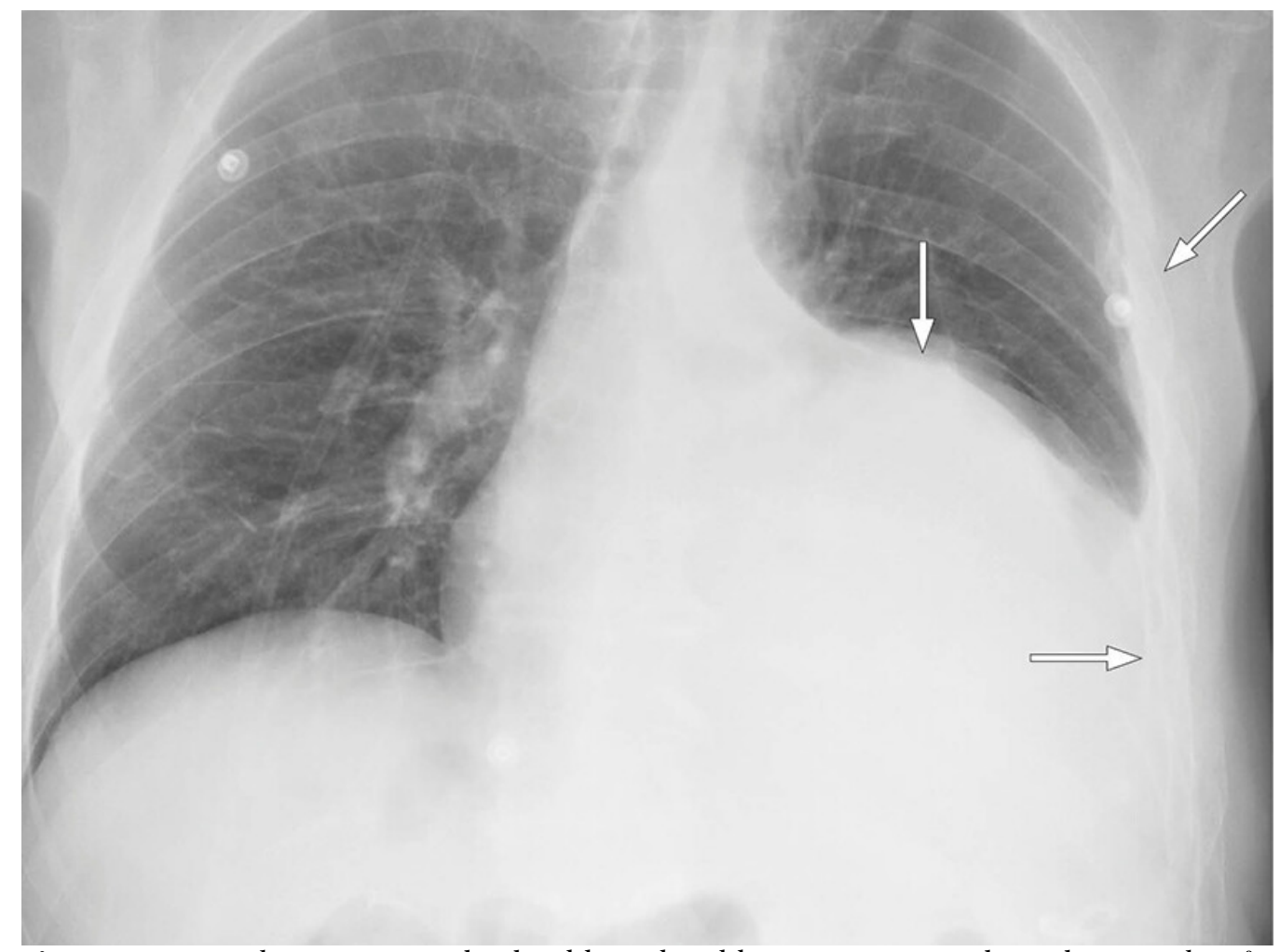

Figur 1 Røntgen thorax viser multiple ribbeinsbrudd og en stor ansamling pleuravæske på venstre side. 


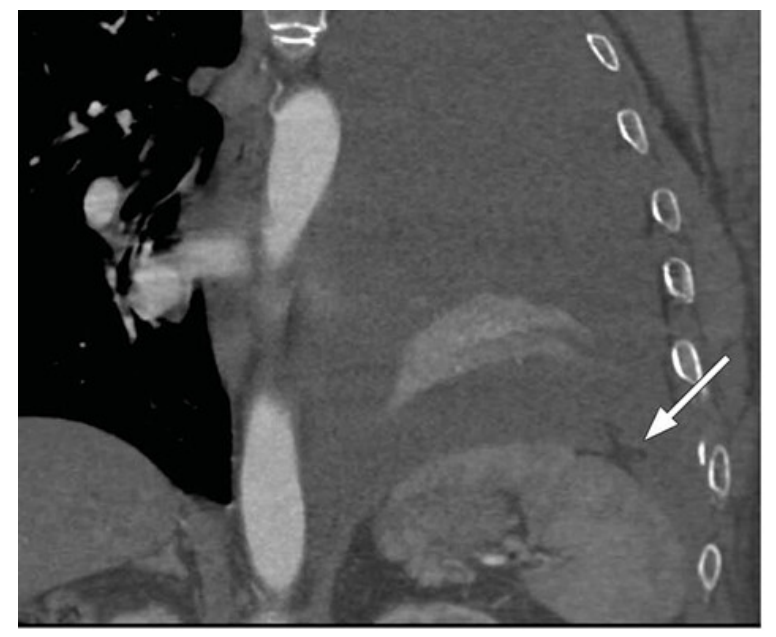

a

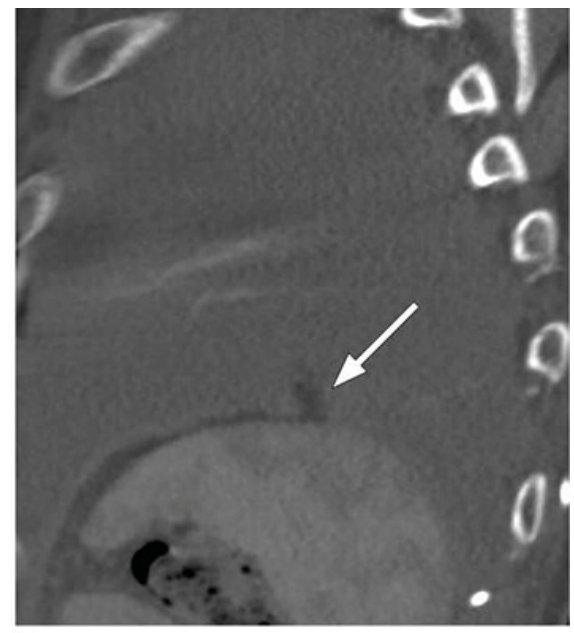

b

Figur 2 CT thorax med intravenøs kontrast og koronal (a) og sagittal (b) rekonstruksjon viser en liten defekt i venstre diafragma med herniering av en fettholdig konfigurasjon opp i venstre pleura. Denne representerer det lille stykket blødende oment.

Ved videoassistert torakoskopi samme kveld fant man anterolateralt blødende oment gjennom en defekt i diafragma. Torakoskopisk fjernet man det blødende omentet og lukket defekten. Pasienten ble samtidig laparoskopert uten funn av ytterligere lesjoner i abdomen. Det postoperative forløpet var ukomplisert, og pasienten ble utskrevet i velbefinnende syv dager etter inngrepet.

\section{Diskusjon}

Den vanligste skademekanismen for stumpe thoraxskader er fall eller trafikkulykker. Antall ribbeinsbrudd er assosiert med traumeenergi og risiko for intra- og ekstratorakale skader $(\underline{1}, \underline{2})$. Ved St. Olavs hospital ble det observert hemothorax hos $7 \%$ av pasientene innlagt med thoraxtraume (1). Diafragmaruptur rapporteres hos under $1 \%$ med stumpt thoraxtraume, og assosieres med høy traumeenergi og alvorlige intratorakale eller intraabdominale $\operatorname{skader}(\underline{1}, 3)$.

Førstelinjebehandling ved hemothorax er pleuradrenasje. Pasientene har, blant annet, risiko for senfølger som fibrosering og empyem (4,.5). Inkomplett drenasje ses i 5-30 \% av tilfellene. Amerikanske retningslinjer anbefaler tidlig videoassistert torakoskopi tre til syv dager etter traumet ved manglende effekt av drenbehandling (4.). Intrapleural fibrinolyse anbefales når risikoen ved kirurgisk inngrep er økt. En nyere litteraturgjennomgang av behandling med alteplase antyder at denne er både trygg og effektiv (5).

Blødningskomplikasjoner ble sett hos o-6,6\%, og blant de konsensusbaserte kontraindikasjonene nevnes kirurgi, blødning eller traume innenfor de siste to døgn (5).

I denne kasuistikken ga behandlingen vesentlig forverring av pasientens tilstand før den tilgrunnliggende årsaken ble identifisert og korrigert. Fibrinolysebehandling ble foretrukket på grunn av tiden siden traumet og pasientens klinisk stabile tilstand og betydelige komorbiditet, herunder diabetes og pankreatitt. Ved gjennomgang av CTbildene fra den første innleggelsen og de senere røntgenbildene ses ikke tegn til diafragmaruptur. Diagnosen er sjelden og kan være klinisk og radiologisk vanskelig å stille, men bør overveies hos pasienter med relevant høyenergitraume (3).

Langt de fleste thoraxskader er et resultat av lavenergitraumer og ferdigbehandles i primærhelsetjenesten, hvor fokuset tradisjonelt har vært å sikre tilstrekkelig smertebehandling for å forhindre forlenget funksjonsnedsettelse, respirasjonsinsuffisiens og pneumoni. Risikoen for pneumoni er omkring $2 \%$, mens risikoen for forsinket pleuraeffusjon beskrives å være 7,4-11,8 \% ved mindre thoraxskader (므). Med utgangspunkt i en kohortstudie er det utviklet et risikostratifiseringsverktøy for å identifisere pasienter 
med høy risiko for utvikling av forsinket pleuraeffusjon (2 2 .) Ved behandling av mindre thoraxtraumer i primærhelsetjenesten bør man være oppmerksom på risikoen for forsinket pleuraeffusjon ved manglende bedring. Hos pasienter med innleggelseskrevende thoraxtraume bør man overveie rutinemessig røntgenkontroll etter syv til ti dager.

Pasienten har gitt samtykke til at artikkelen blir publisert.

Artikkelen er fagfellevurdert.

\section{LITTERATUR}

1. Kjøs HO, Lande TMZ, Eriksson U et al. Thoraxskader ved et regionalt traumesenter. Tidsskr Nor Legeforen 2007; 127:1496-9. [PubMed]

2. Émond M, Guimont $C$, Chauny JM et al. Clinical prediction rule for delayed hemothorax after minor thoracic injury: a multicentre derivation and validation study. CMAJ Open 2017; 5: E444-53. [PubMed][CrossRef]

3. Fair KA, Gordon NT, Barbosa RR et al. Traumatic diaphragmatic injury in the American College of Surgeons National Trauma Data Bank: a new examination of a rare diagnosis. Am J Surg 2015; 209: 8648. [PubMed][CrossRef]

4. Mowery NT, Gunter OL, Collier BR et al. Practice management guidelines for management of hemothorax and occult pneumothorax. J Trauma 2011; 70: 510-8. [PubMed][CrossRef]

5. Holsen MR, Tameron AM, Evans DC et al. Intrapleural tissue plasminogen activator for traumatic retained hemothorax. Ann Pharmacother 2019; 53: 1060-6. [PubMed][CrossRef]

Publisert: 17. februar 2021. Tidsskr Nor Legeforen. DOI: 10.4045/tidsskr.20.0717

Mottatt 6.9.2020, første revisjon innsendt 1.12.2020, godkjent 22.12.2020.

Publisert under åpen tilgang CC BY-ND. Lastet ned fra tidsskriftet.no 26. april 2023. 